\title{
The Histopathological and Ultrastructural Effects of the Topical Application of Bacitracin on the Cerebral Cortex in Rats
}

\author{
Suçan Beyin Korteksi Üzerine Topikal Basitrasin Uygulanmasımn \\ Histopatolojik ve Ultrastrïktürel Etkileri
}

Erdal Resit YILMAZ ${ }^{1}$, Bora GURER ${ }^{2}$, Hayri KERTMEN ${ }^{1}$, Askin Esen HASTURK ${ }^{3}$, Oya EVIRGEN ${ }^{4}$, Nazli HAYIRLI ${ }^{4}$, Hilal GOKTURK ${ }^{5}$, Belgin CAN $^{4}$, Yusuf Sukru CAGLAR ${ }^{6}$, Zeki SEKERCI $^{1}$

${ }^{1}$ Ministry of Health, Diskapi Yildirim Beyazit Education and Research Hospital, Neurosurgery Clinic, Ankara, Turkey

${ }^{2}$ Ministry of Health, Fatih Sultan Mehmet Education and Research Hospital, Department of Neurosurgery, Istanbul, Turkey

${ }^{3}$ Ministry of Health, Oncology Education and Research Hospital, Department of Neurosurgery, Ankara, Turkey

${ }_{4}^{4}$ Ankara University, School of Medicine, Department of Histology and Embryology, Ankara, Turkey

5Yildirim Beyazit University, School of Medicine, Department of Histology and Embryology, Ankara, Turkey

${ }^{6}$ Ankara University, School of Medicine, Department of Neurosurgery, Ankara, Turkey

Corresponding Author: Bora GURER / E-mail: boragurer@gmail.com

\section{ABSTRACT}

AIM: Bacitracin is one of the most frequently used agents for the topical irrigation of the cerebral cortex. The aim of this study is to investigate whether bacitracin has histopathological and ultrastructural effects when applied topically to the cerebral cortex.

MATERIAL and METHODS: Twenty-eight rats were randomly assigned to four groups. Except the control group, each rat underwent left frontoparietal craniectomy with dural removal. Then, in the sham group a piece of dry absorbable gelatin sponge was placed over the left hemisphere; in the saline group a gelatin sponge soaked in normal saline; and in the bacitracin group a gelatin sponge soaked in 500 units bacitracin was used. After 48 hours, brain tissues were extracted for histopathological and electron microscopic analyses.

RESULTS: Among the four groups dark stained neurons were found to be statistically higher in number in the bacitracin group compared with the control, sham and saline groups. Electron microscopic evaluation revealed that, in the bacitracin group, almost all cytoplasmic organelles were poorly preserved.

CONCLUSION: Topical application of the bacitracin on to the cerebral cortex caused histopathological and ultrastructural changes in the neural tissue. These changes may be an evidence for the neurotoxic effects of bacitracin.

KEYWORDS: Bacitracin, Cerebral cortex, Neurotoxicity, Neurosurgery, Rat, Topical

öz

AMAÇ: Basitrasin serebral korteksin topikal irrigasyonu için en sık kullanılan ajanlardan bir tanesidir. Bu çalışmada basitrasinin serebral korteks üzerinde histopatolojik ve ultrastrüktürel bir etkisinin olup olmadığı incelenmiştir.

YÖNTEM ve GEREÇLER: Yirmi sekiz sıçan randomize olarak dört gruba ayrıldı. Kontrol grubu hariç her grubta sol frontopariyetal kraniektomi yapıldı ve dura eksize edildi. Takiben sham grubunda sol hemisfer üzerine kuru jelatin sponge, salin grubunda salin emdirilmiş jelatin sponge ve basitrasin grubunda ise 500 ünite basitrasin emdirilmiş jelatin sponge konuldu. Kırk sekiz saat sonra beyin dokuları histopatolojik ve elekton mikroskobik analiz için çıkartıldı.

BULGULAR: Dört grup arasında karşılaştırma yapıldığında "siyah boyanmış nöronların" basitrasin grubunda diğer gruplardan daha fazla izlendiği tespit edildi. Elektron mikroskobik incelemede ise basitrasin grubunun sitoplazmik organellerinin ciddi şekilde tahrip olduğu izlendi. SONUÇ: Basitrasinin serebral korteks üzerine topikal uygulanması nöral dokuda histopatolojik ve ultrastrüktürel değişikliklere neden olmuştur. Bu değişiklikler basitrasinin nörotoksik etkisinin bir göstergesi olabilir.

ANAHTAR SÖZCÜKLER: Basitrasin, Serebral korteks, Nörotoksisite, Nöroşirürji, Sıçan, Topikal

\section{INTRODUCTION}

In clean neurosurgical procedures, the incidence of postoperative deep or superficial wound infections is possibly low. However, when it occurs, this complication may have catastrophic consequences. It is therefore essential to keep postoperative infection to an absolute minimum. The majority of authors have reported the beneficial effects of systemic antibiotics $(3-5,9-14,17,19,20)$. Topical irrigation with antibiotics in neurosurgical operations remains controversial in the prevention of the wound infections $(2,9-11,17,26,30$, $34,36,38)$. 
Bacitracin is a peptide antibiotic produced by Bacillus subtilis and exhibits activity against Gram-positive organisms (22). Bacitracin is one of the most popular topical antibiotics used in the irrigation solution for neurosurgical cases $(25,31,33,37)$. Although the systemic toxic effects have been investigated extensively (31), no such published data regarding the neurotoxic effects of bacitracin when used topically were found.

The aim of this study was to investigate whether bacitracin has histopathological and ultrastructural effects when applied topically to the cerebral cortex.

\section{MATERIAL and METHODS}

\section{Experimental Groups}

Animal care and all experiments were in concordance with the European Communities Council Directive of November 24, 1986 (86/609/EEC) on the protection of animals for experimental use. All experimental procedures used in this investigation were reviewed and approved by ethical committee of Ministry of Health Refik Saydam Hifzissiha Institution. Twenty-eight adult male Wistar Albino rats weighing 250-350g were used. The rats were randomly assigned to four groups as follows:

Group 1: Control ( $n=7)$; no surgical intervention performed. Normal brain tissues were obtained.

Group 2: Sham $(n=8)$; rats underwent craniectomy as described below. Dry gelatin sponge (Spongostan, Johnson \& Johnson, USA) was placed on to the brain. Brain samples were removed 48-h after the procedure.

Group 3: Saline $(\mathrm{n}=7)$; rats underwent craniectomy as described below. Gelatin sponge soaked in $1 \mathrm{cc} 0.9 \%$ normal saline solution was placed on to the brain. Brain samples were removed 48-h after the procedure.

Group 4: Bacitracin ( $n=6)$; rats underwent craniectomy as described below. Gelatin sponge soaked in 1 cc of 500 units bacitracin (Bacitracin, Pharmacia \& Upjohn, USA) was placed on to the brain. Brain samples were removed $48 \mathrm{~h}$ after the procedure.

\section{Anesthesia and Craniectomy Procedure}

All rats were kept under environmentally controlled conditions at $22-25^{\circ} \mathrm{C}$ with appropriate humidity and a $12-\mathrm{h}$ light cycle, and granted free access to food and water. The animals were anesthetized by an intraperitoneal injection of $10 \mathrm{mg} / \mathrm{kg}$ xylazine (Rompun ${ }^{\circledR}$, Bayer, Turkey) and 50 $\mathrm{mg} / \mathrm{kg}$ ketamine (Ketalar ${ }^{\circledR}$, Parke Davis, Turkey) and allowed to breathe spontaneously. A rectal probe was inserted and the animals were positioned on a heating pad in order to maintain the body temperature at $37^{\circ} \mathrm{C}$. The rats were placed in a prone position on the table. Midline skin incision was made on the head, and the coronal and the lambdoid sutures were observed. Each rat (except for Group 1) underwent left frontoparietal craniectomy with dural removal. Then, in the sham group, a piece of dry absorbable gelatin sponge of
$0.5 \times 0.5 \mathrm{~cm}$. was placed over the left hemisphere; in the saline group, exactly the same size of absorbable gelatin sponge soaked in $0.9 \%$ normal saline solution; and in the bacitracin group, an absorbable gelatin sponge of the same size soaked in 500 units bacitracin was used. After the procedure the skin was sutured before termination of anesthesia.

All animals were anesthetized with the above-mentioned agents $48 \mathrm{~h}$ after the procedure, and their brains were extracted immediately without any damage. Samples of neural tissues were obtained by excising left frontoparietal lobes from the boundary of the interhemispheric fissure and were subjected to light and electron microscopic analyses.

\section{Tissue Processing for Light Microscopy}

Brain tissue samples were fixed in $10 \%$ buffered formalin, dehydrated through a graded series of ethanol and processed for light microscopy according to routine methods. The paraffin blocks were then cut into sections of 5 - $\mu \mathrm{m}$ thickness, stained with hematoxylin-eosin (H\&E), and examined by light microscopy (Olympus, model: CX21FS1).

Sections from each rat were selected for quantification of the number of the dark stained neurons (DSN) in the cerebral cortex. At the middle of the cerebral cortex, two fields were chosen randomly using the $\mathrm{X} 40$ objective on each section. An ocular micrometer with a $100 \mu \mathrm{m} \times 100 \mu \mathrm{m}$ counting grid area was used. Cortical neurons were counted by two observers who were blinded to the study groups. The neurons with euchromatic large nuclei were considered as normal while the neurons having a shrunken, hyperchromatic, basophilic perikaryon, which were darkly stained, were accepted as degenerating or dying neurons. DSN were previously shown to be indicators of neuronal death and degeneration (24). Non-neuronal cells such as glial cells (distinguished from neurons according to cell size, nuclear shape, cytoplasm location, and characteristic staining patterns of chromatin), pericytes and endothelial vascular cells were excluded.

The number and percent of normal neurons and DSN were defined as the average of two microscopic fields in each rat, and then the data were expressed as the mean and standard derivation (SD) of the counts. For the quantification of perivascular cell infiltration and gliosis, the cerebral cortex was evaluated for each rat of every group under a light microscope and represented as the number and the percent of animals of each group.

\section{Tissue Processing for Electron Microscopy}

For electron microscopy, brain specimens were fixed by immersion in $2.5 \%$ glutaraldehyde in $0.1 \mathrm{M}$ phosphate buffer (pH 7.4) for $4-6 \mathrm{~h}$ at $4{ }^{\circ} \mathrm{C}$, post-fixed in $1 \%$ osmium tetroxide for $2 \mathrm{~h}$, dehydrated in an ascending alcohol series, and embedded in araldite. Semithin sections stained with toluidine blue were examined under light microscopy. Ultrathin sections stained with uranyl acetate and lead citrate were observed under the LEO $900 \mathrm{E}$ transmission electron microscope (Carl-Zeiss, Germany). 


\section{Statistical Analysis}

Data analyses were performed using SPSS for Windows, version 11.5 (SPSS Inc., Chicago, IL, USA). Statistical analyses were performed using Fischer's exact test for cell infiltration around blood vessels. The Kruskal-Wallis test and Chi-square test were applied to evaluate the number and percent of normal neurons and DSN in the cerebral cortex. A " $p$ " value less than 0.05 was considered statistically significant.

\section{RESULTS}

\section{Light Microscopy}

Light microscopic examination of the cerebral cortices from the control group showed a normal cellular composition with neurons and neuroglial cells. The brain parenchyma neuropil was homogeneous in appearance (Figure 1A).
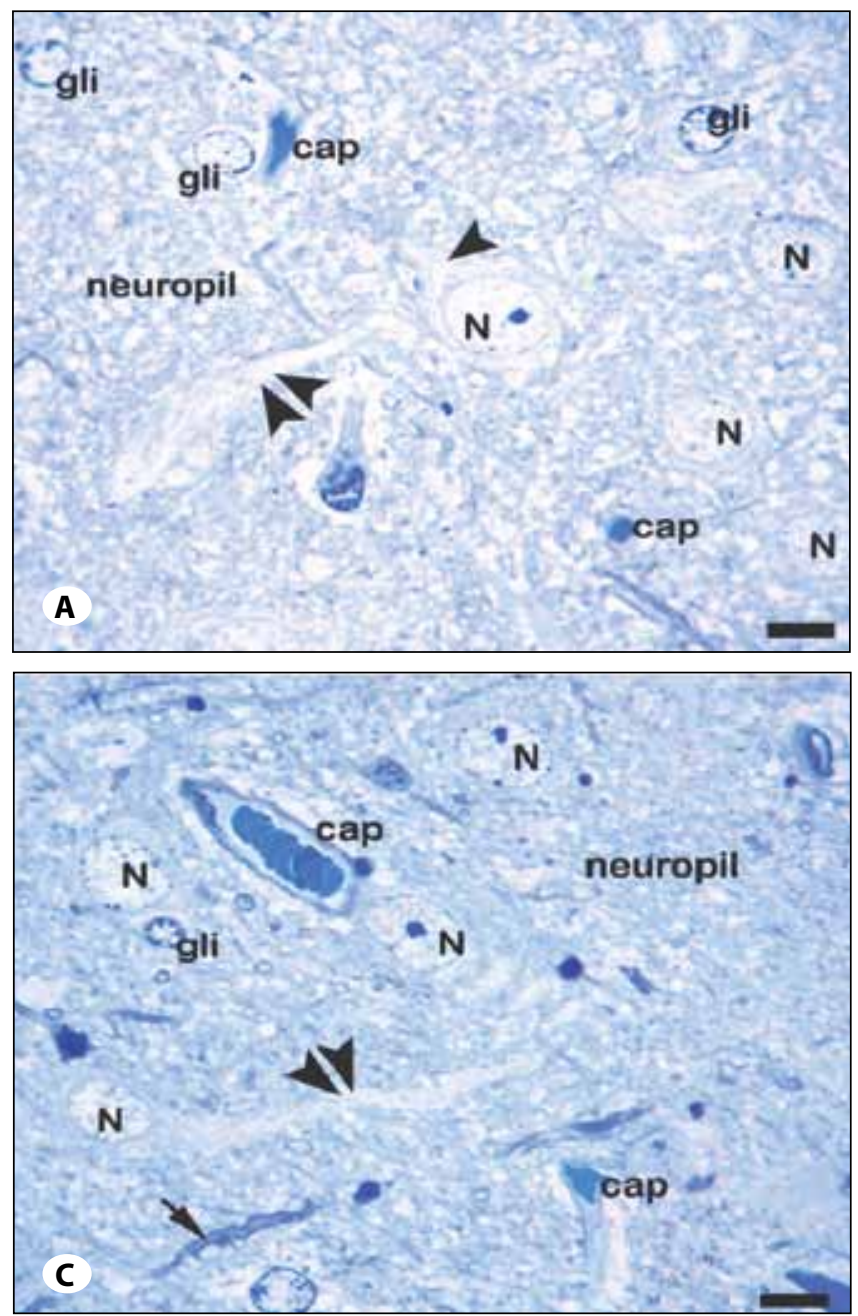

The sham and the saline groups also showed normal structure of the neuronal and non-neuronal cells and neuropil containing cell processes, myelinated fibers and blood vessels (Figure 1B, C).

The bacitracin group demonstrated perivascular edema around blood vessels in the cerebral cortex. Mast cells were identified with metachromatic (deep violet) staining pattern and were closely associated with blood vessels. Some of the neuronal cells showed dark stained shrunken cytoplasm with dense nuclei (Figure 1D).

There was no statistically significant difference between study groups in terms of cell infiltration and gliosis around blood vessels (Figure 2A-D). Among the four groups, the DSN number was statistically higher in the bacitracin group when compared with the control, sham and saline groups $(p<0.05)$ (Table I).
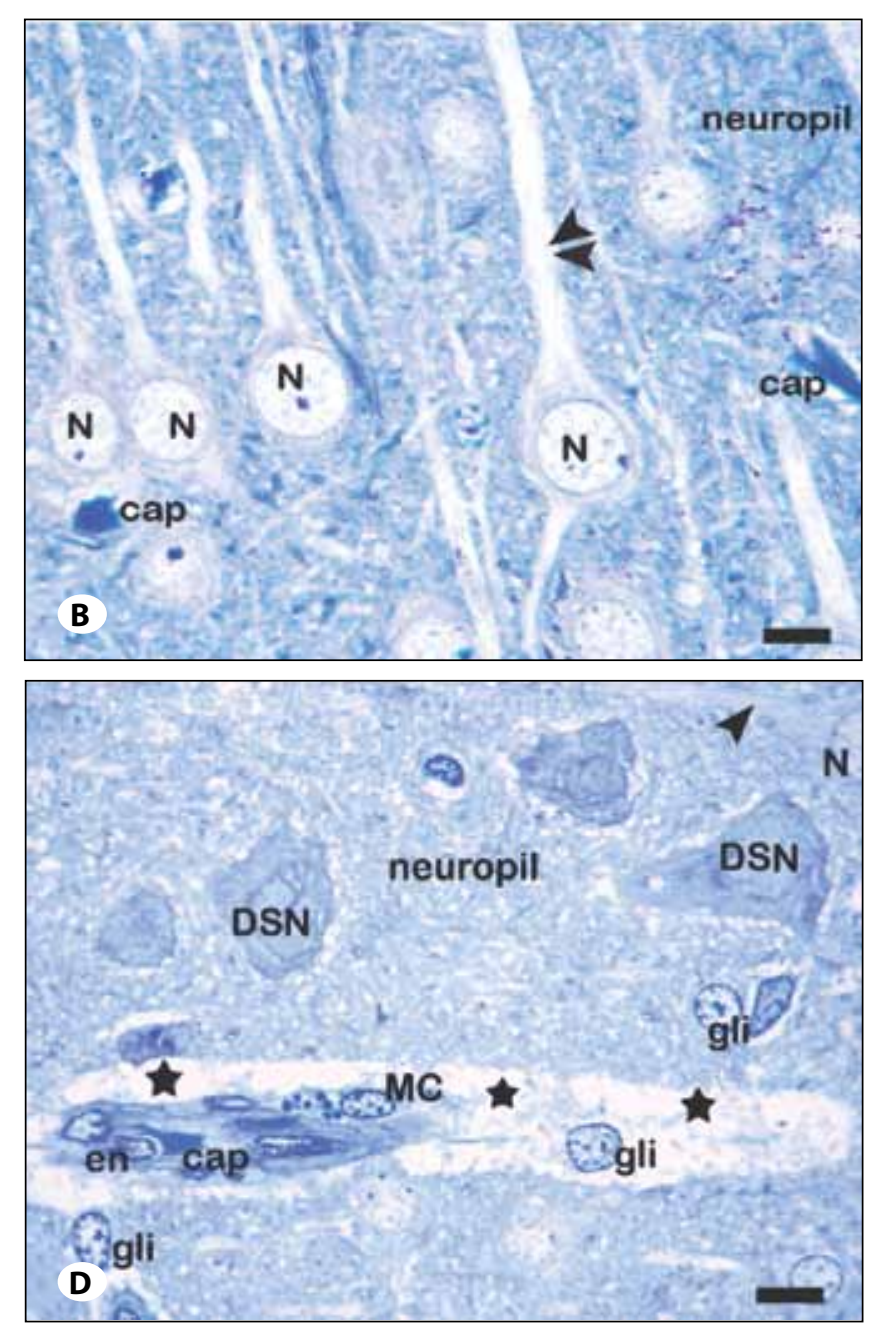

Figure 1: Toluidine blue staining of the specimens. (x100 obj) A) Control, B) sham and C) saline groups showed normal structure of the neuronal and non-neuronal cells and neuropil containing cell processes, myelinated fibers and blood vessels. D) The bacitracin group demonstrated perivascular edema around blood vessels in the cerebral cortex. Mast cells closely associated with blood vessels were identified. Dark strained neurons were also shown. N: nucleus; arrowhead: cytoplasm of a neuron; gli: glial cells; double arrowhead: cytoplasmic projections of neurons; cap: blood capillaries in cerebral cortex; arrow: myelinated fiber; DSN: dark stained neurons; star: blood vessel showing perivascular edema; MC: mast cell containing metachromatic granules beside the vessel; en: endothelial cell. 

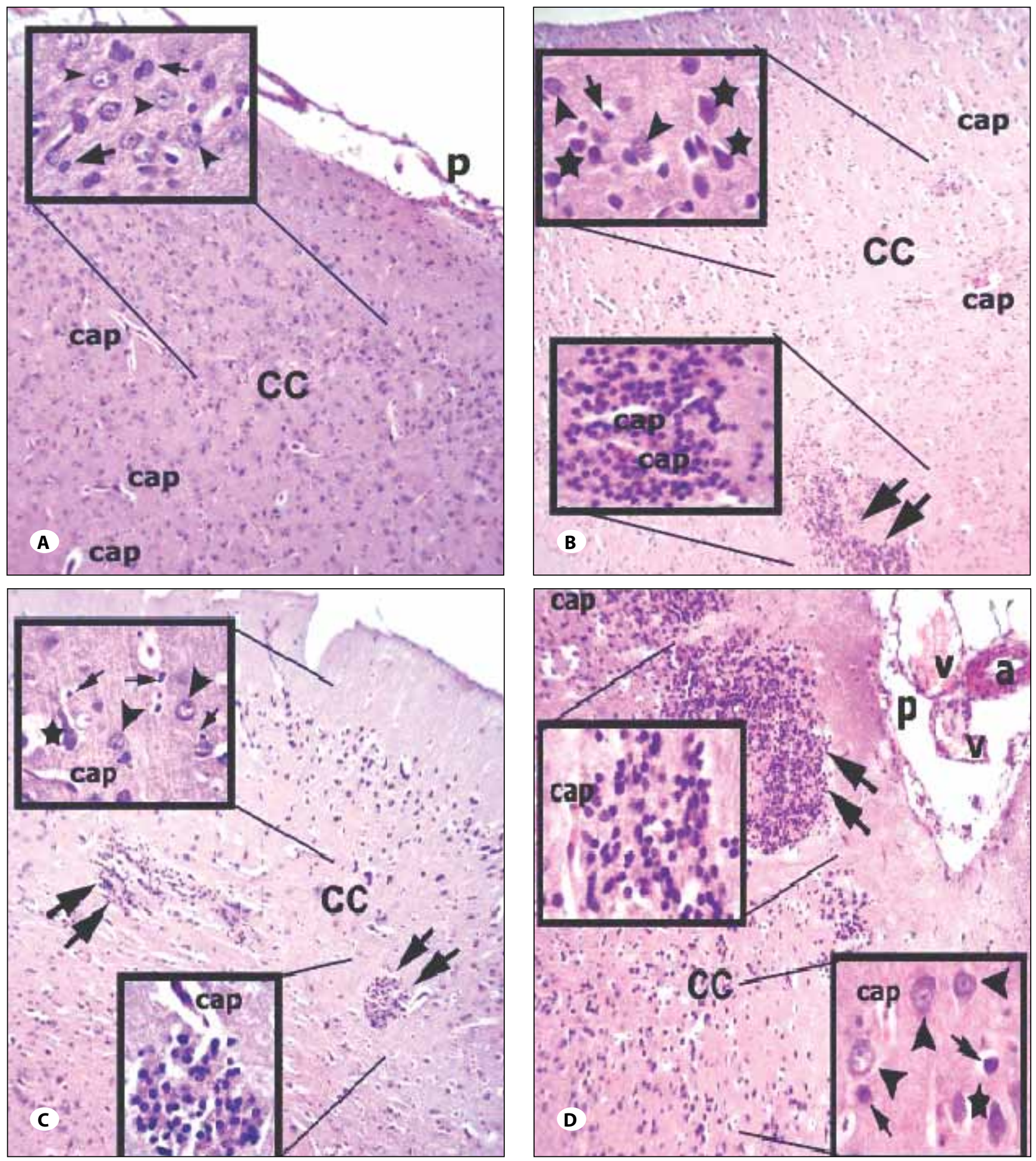

Figure 2: Hematoxylin-Eosin staining of the specimens. Light microscopic examination of the cerebral cortex from the control group A) showed a normal cellular composition with normal appearing neurons. B) The sham and C) the saline groups showed mild perivascular cell infiltration and gliosis. D) The bacitracin group also showed perivascular cell infiltration, gliosis and dark stained neurons. Inlets show areas at higher magnification. (Low magnification: x20 obj and high magnification: x100 obj). CC: cerebral cortex; p: piamater; cap: capillary; arrow: normal appearing glial cells; arrowhead: normal appearing neurons; double arrows: perivascular cell infiltration and gliosis areas; star: dark stained neuron. 
Table I: Total Neuron Number, Dark Stained Neuron Number and Percentage in Each Group

\begin{tabular}{|c|c|c|}
\hline Groups & $\begin{array}{c}\text { Total neuron } \\
\text { number } \\
\text { (Mean士SD (\%)) }\end{array}$ & $\begin{array}{l}\text { DSN number } \\
\text { and percentage } \\
\text { (Mean士SD (\%)) }\end{array}$ \\
\hline Control & $59.66 \pm 18.08$ & $13.83 \pm 8.88(19 \%)$ \\
\hline Sham & $58.16 \pm 22.74$ & $18 \pm 3.57(24 \%)$ \\
\hline Saline & $62.16 \pm 23.53$ & $18 \pm 3.52(23 \%)$ \\
\hline Bacitracin & $57 \pm 16.80$ & $31 \pm 8.85(36 \%)^{*}$ \\
\hline
\end{tabular}

DSN: Dark stained neurons. There were statistically significant differences found when bacitracin group was compared to control, sham and saline groups ( $p<0.05$ for all comparisons).
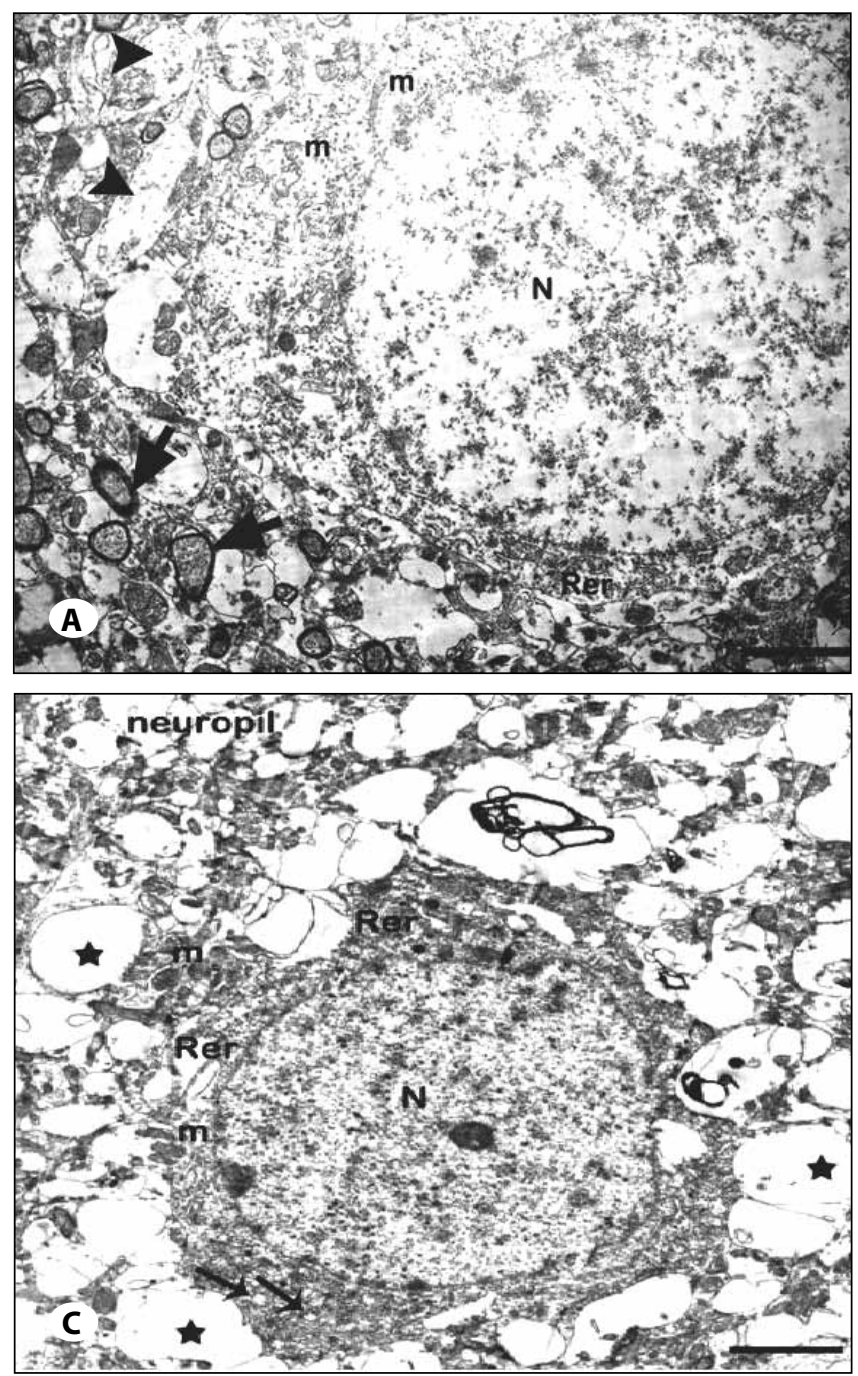

\section{Electron Microscopy}

Electron microscopic observations revealed that the control group showed neurons with intact cellular organelles (Figure 3A). In the sham and the saline groups, perinuclear cytoplasmic organelles were intact in general, but there was mild dilatation of the rough endoplasmic reticulum. Some mitochondria demonstrated disorganization and vacuolization in the neuropil (Figure $3 \mathrm{~B}, \mathrm{C}$ ). In the bacitracin group, almost all the cytoplasmic organelles were poorly preserved. Dilatation of the rough endoplasmic reticulum and intracristal swelling of mitochondria were evident. There were few ribosomes scattered in vacuolated cytoplasm.
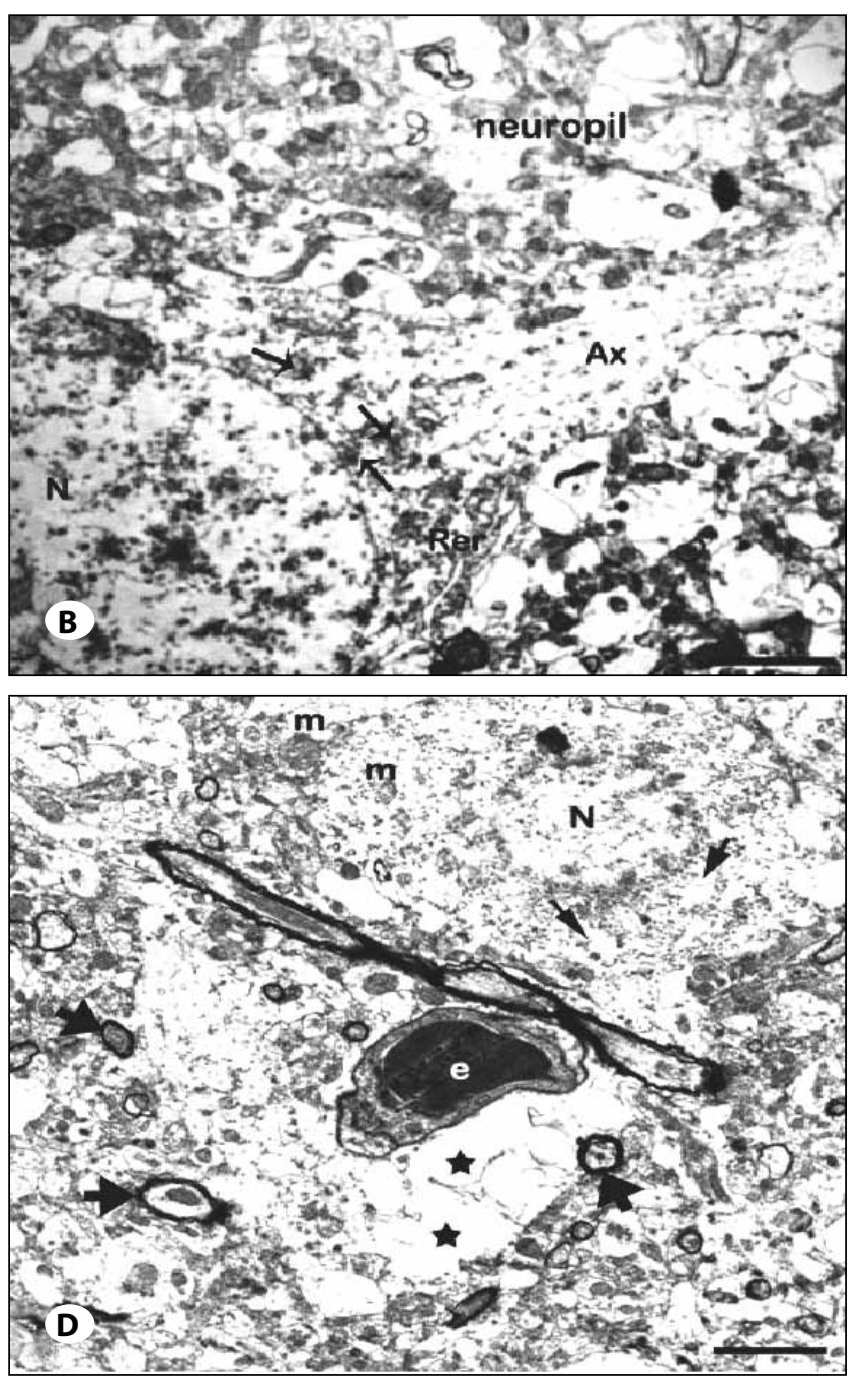

Figure 3: Electron micrographs of the groups. A) Control group showing neurons with intact cellular organelles. Cytoplasm includes rough endoplasmic reticulum and plentiful free ribosomes close to the rough endoplasmic reticulum. Rer: rough endoplasmic reticulum; m: mitochondria; N: nucleus of a neuron; arrowhead: cytoplasmic extensions; arrow: myelinated fibers. B) Sham group showing free ribosomes in electron lucent perinuclear cytoplasm (arrows). Rer: rough endoplasmic reticulum; N: nucleus of a neuron; Ax: axon hillock. C) Saline group showing mild dilatation (arrow) of the rough endoplasmic reticulum (Rer), and some vacuoles in neuropil (star). Rer: rough endoplasmic reticulum; $\mathbf{m}$ : mitochondria; N: nucleus of a neuron. D) Bacitracin group showing disorganized mitochondria $(\mathrm{m})$ and few ribosomes, vacuoles indicating dilatation of rough endoplasmic reticulum (thin arrows) and perivascular edema (stars) around parenchymal blood vessel filled with erythrocytes (e). N: nucleus of a neuron; thick arrows: myelinated fibers. Bar. $2500 \mathrm{~nm}$. 
Perivascular edema around blood vessels, and dilated cell processes were seen (Figure 3D).

\section{DISCUSSION}

Postoperative wound infection is an important, preventable cause of mortality and morbidity in neurosurgical practice. In general, postoperative infection rates in clean neurosurgical wounds range from 0.8 to $6 \%$ with $3-4 \%$ being the expected average rate (29). Prophylactic use of antibiotics in clean neurosurgical operations remains controversial $(16,23)$. Most of the studies published on this subject indicate the use of prophylactic antibiotics in neurosurgical operations $(5,12-14$, $17,23,28,29,32,38)$. Barker (2) and Haines and Walters (18) reported that their meta-analysis of published randomized studies comparing prophylactic antibiotics to a placebo showed that antibiotics were advantageous in craniotomies.

Topical irrigation of neurosurgical incisions with antibiotics has had proponents and opponents $(34,35)$. In daily neurosurgical practice, more than a few neurosurgeons use topical antibiotics in their irrigation solutions.

Bacitracin is a polypeptide antibiotic, produced by a strain of Bacillus subtilis. This strain was isolated from a compound fracture in a young girl named Tracy in 1943, adopting the name "bacitracin". Since its discovery, bacitracin has been widely used to treat various infections. In a concentration of less than 5 units per milliliter, bacitracin inhibits the growth of a variety of gram-positive cocci and bacilli, Neisseria, $\mathrm{H}$. influenza, and Fusobacterium. Higher concentrations are bactericidal (25).

In neurosurgical practice, bacitracin concentrations varying from 500 to 5000 units/ml have been used in the irrigation fluid $(15,21,27,37)$. Furthermore, it was reported that bacitracin was not epileptogenic even at the highest concentrations when applied topically (31) and this has increased the popularity of its use in irrigation fluids. However, we showed that topical application of bacitracin to the cerebral cortex has neurotoxic effects in this study.

There is no previous study on the toxic effects of topical application of the bacitracin to the cerebral cortex. In this study, light microscopic evaluation of the tissues revealed statistically significant higher number of DSN in the bacitracin group when compared to the control, sham and saline groups. Dark stained neurons are considered by many neuropathologists to be morphological changes indicating a variety of biochemical, ischemic, or toxic insults $(1,6-8,24)$. According to the criteria of Cammermeyer (7), these DSN appear to be in vivo phenomena and differ from the solitary dark neurons ascribed to post-mortem artifact. In our study, the control, sham and saline groups had fewer DSN than the bacitracin group, indicating that DSN may be an indicator for the neurotoxicity of topical bacitracin. The presence of perivascular edema and mast cells close to the blood vessels in the bacitracin group may also indicate a disruption of bloodbrain barrier integrity. A major controversial point related to DSN is whether these cells can regain their normal functions.
However, DSN represents a reactive neuronal change in cells, and they can survive for a considerable period of time (1).

Electron microscopic evaluation of the bacitracin group revealed that cytoplasmic organelles were poorly preserved. The rough endoplasmic reticulum was dilated, and intracristal swelling of mitochondria and a vacuolated cytoplasm were observed. Perivascular edema and dilated cell processes were seen in the neuropil. These results show that topical usage of bacitracin caused ultrastructural changes in the neurons.

This study has some limitations. The number of rats in each group could be increased. More diluted and concentrated dosages may be investigated. Later biochemical assessment may provide better results in further studies. Another limitation of this study is the lack of functional outcome measures.

\section{CONCLUSION}

In conclusion, topical application of the bacitracin on to the cerebral cortex may induce local inflammation via mast cells that causes histopathological and ultrastructural changes in the neural tissue. These histopathological and ultrastructural changes may be the evidence regarding the neurotoxic effects of bacitracin used in irrigation solutions. More studies are needed to assess the safety of bacitracin before its use in irrigation solutions.

\section{REFERENCES}

1. Aguis L, Hadjiconstantinou M, Qu ZX, Neff NH, Pearl DK, Yates AJ: GM1 ganglioside and darkly staining neurons in brains of rats subjected to neonatal hypoxia-ischemia. Int J Dev Neurosci 12: 623-630, 1994

2. Barker FG: Efficacy of prophylactic antibiotics for craniotomy: A meta-analysis. Neurosurgery 35: 484-492, 1994

3. Blomstedt GC, Kytta J: Results of a randomized trial of vancomycin prophylaxis in craniotomy. J Neurosurg 69: 216-220, 1988

4. Brown EM: Antimicrobial prophylaxis in neurosurgery. $\mathrm{Br} J$ Neurosurg 1: 159-161, 1987

5. Bullock R, van Dellen JR, Ketelbey W, Reinach SG: A doubleblind placebo-controlled trial of perioperative prophylactic antibiotics for elective neurosurgery. J Neurosurg 69:687-691, 1988

6. Cammermeyer J: Histochemical phospholipid reaction in ischemic neurons as an indication of exposure to postmortem trauma. Exp Neurol 49: 252-271, 1975

7. Cammermeyer J: Is the solitary dark neuron a manifestation of postmortem trauma to the brain inadequately fixed by perfusion? Histochemistry 56: 97-115, 1978

8. Cammermeyer J: The effect of postmortem trauma on neuronal cell types stained histochemically for phospholipids. Exp Neurol 46: 616-633, 1975

9. Cartmill TD, al Zahawi MF, Sisson PR, Ingham HR, Gould FK, Crone PB, Betty MJ, Crawford PJ, Kalbag RM, Mendelow $A D$, Sengupta RP: Five days versus one day of penicillin as prophylaxis in elective neurosurgical operations. J Hosp Infect 14: 63-68, 1989 
10. Choux M, Genitori L, Lang D, Lena G: Shunt implantation: Reducing the incidence of shunt infection. J Neurosurg 77: 875-880, 1992

11. Dempsey R, Rapp RP, Young B, Johnston S, Tibbs P: Prophylactic parenteral antibiotics in clean neurosurgical procedures: A review. J Neurosurg 69: 52-57, 1988

12. Djindjian M, Lepresle E, Horns JB: Antibiotic prophylaxis during prolonged clean neurosurgery: Results of a randomized double-blind study using oxacillin. J Neurosurg 73: 383-386, 1990

13. Gaillard T, Gilsbach JM: Intra-operative antibiotic prophylaxis in neurosurgery: A prospective, randomized, controlled study on cefotiam. Acta Neurochir (Wien) 113: 103-109, 1991

14. Geraphty J, Feely M: Antibiotic prophylaxis in neurosurgery. A randomized controlled trial. J Neurosurg 60: 724-726, 1984

15. Gibson RM: Application of antibiotics (polybactrin) in surgical practice, using the aerosol technique. Br Med J 1: 1326-1327, 1958

16. Goldstein A, Raggueneau JL, Kind A, Moret G, George B: Prophylactic antibiotherapy in neurosurgery. Agressologie 24: 233-236, 1983

17. Haines SJ, Goodman ML: Antibiotic prophylaxis of postoperative neurosurgical wound infection. J Neurosurg 56: 103-105, 1982

18. Haines SJ, Walters BC: Antibiotic prophylaxis for cerebrospinal fluid shunts: A metaanalysis. Neurosurgery 34: 87-92, 1994

19. Haines SJ: Antibiotic prophylaxis in neurosurgery: The controlled trials. Neurosurg Clin N Am 3: 355-358, 1992

20. Haines SJ: Efficacy of antibiotic prophylaxis in clean neurosurgical operations. Neurosurgery 24: 401-405, 1989

21. Haines SJ: Topical antibiotic prophylaxis in neurosurgery. Neurosurgery 11: 250-253, 1982

22. Ikai $Y$, Oka H, Hayakawa J, Matsumoto M, Saito M, Harada K, Mayumi Y, Suzuki M: Total structures and antimicrobial activity of bacitracin minor components. J Antibiot (Tokyo) 48: 233-242, 1995

23. Ingham HR, Kalbag RM, Sisson PR, Allcutt DA, Betty MJ, Crawford PJ, Gillham NR, Hankinson J, Sengupta RP, Strong AJ, Sinar EJ, Crone PB, Gillham M, Gould FK, Hudson SJ, Wardle JK, Cartmill TDI, Stokes ER: Simple peroperative antimicrobial chemoprophylaxis in elective neurosurgical operations. J Hosp Infect 12: 225-233, 1988

24. Jortner BS: The return of the dark neuron. A histological artifact complicating contemporary neurotoxicologic evaluation. Neurotoxicology 27: 628-634, 2006
25. Kartush JM, Cannon SC, Bojrab DI, Graham MD, Schmaltz $\mathrm{S}$, Kemink JL: Use of bacitracin for neurotologic surgery. Laryngoscope 98: 1050-1054, 1988

26. Malis LI: Prevention of neurosurgical infection by intraoperative antibiotics. Neurosurgery 5:339-343, 1979

27. Meleney FL, Johnson BA, Teng P: Further experiences with local and systemic bacitracin in the treatment of various surgical and neurosurgical infections and certain related medical infections. Surg Gynecol Obstet 94: 401-425, 1952

28. Mollman HD, Haines SJ: Risk factors for postoperative neurosurgical wound infection. A case control study. J Neurosurg 64: 902-906, 1986

29. Quartey GR, Polyzoidis K: Intraoperative antibiotic prophylaxis in neurosurgery: A clinical study. Neurosurgery 8: 669-671, 1981

30. Reale F, Biancotti R, De Falco D, Gambacorta D: Antibiotic prophylaxis in neurosurgery. Study comparing two groups of patients with and without treatment. Acta Neurochir (Wien) 86: 75-78, 1987

31. Reid KH, Shields CB, Raff MJ, Cowles LS, Johnson JD: Effect of the topical application of some newer antibiotics on the cerebral cortex. Neurosurgery 20: 868-870, 1987

32. Savitz MH, Katz SS: Prevention of primary wound infection in neurosurgical patients: A 10-year study. Neurosurgery 18 : 685-688, 1986

33. Savitz MH, Katz SS: Rationale for prophylactic antibiotics and neurosurgery. Neurosurgery 9: 142-144, 1981

34. Savitz MH, Malis LI, Meyers B: Prophylactic antibiotics in neurosurgery. Surg Neurol 2: 95-100, 1974

35. Savitz MH, Malis LI: Prophylactic clindamycin for neurosurgical patients. NY State J Med 76: 64-67, 1976

36. Shapiro M, Wald U, Simchen E, Pomeranz S, Zagzag D, Michowiz SD, Samuel-Cahn E, Wax Y, Shuval R, Kahane Y, Sacks T, Shalit M: Randomized clinical trial of intra-operative antimicrobial prophylaxis of infection after neurosurgical procedures. J Hosp Infect 8: 283-295, 1986

37. Teng P, Cohen I, Meleney FL: Bacitracin in neurosurgical infections. Surg Gynecol Obstet 92: 53-63, 1951

38. Winkler D, Rehn H, Freckmann N, Nowak G, Herrmann HD: Clinical efficacy of perioperative antimicrobial prophylaxis in neurosurgery: A prospective randomized study involving 159 patients. Chemotherapy 35: 304-312, 1989 